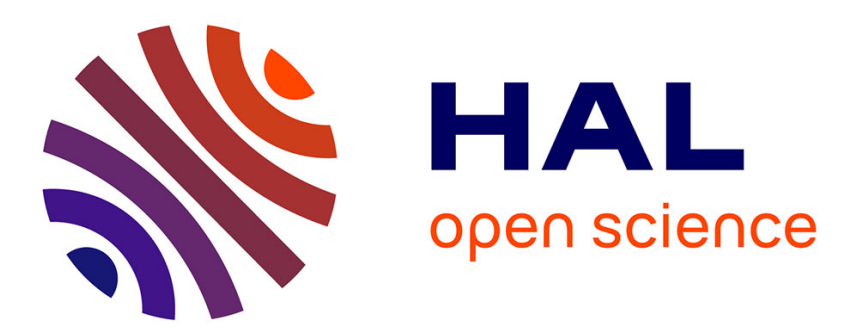

\title{
In situ evaluation of oxidative stress and immunological parameters as ecotoxicological biomarkers in a novel sentinel species (Mimachlamys varia)
}

Thomas Milinkovitch, Paco Bustamante, Valérie Huet, Anaïs Reigner, Carine Churlaud, Hélène Thomas-Guyon

\section{- To cite this version:}

Thomas Milinkovitch, Paco Bustamante, Valérie Huet, Anaïs Reigner, Carine Churlaud, et al.. In situ evaluation of oxidative stress and immunological parameters as ecotoxicological biomarkers in a novel sentinel species (Mimachlamys varia). Aquatic Toxicology, 2015, 161, pp.170 - 175. 10.1016/j.aquatox.2015.02.003 . hal-01119160

\author{
HAL Id: hal-01119160 \\ https://hal.science/hal-01119160
}

Submitted on 21 Feb 2015

HAL is a multi-disciplinary open access archive for the deposit and dissemination of scientific research documents, whether they are published or not. The documents may come from teaching and research institutions in France or abroad, or from public or private research centers.
L'archive ouverte pluridisciplinaire HAL, est destinée au dépôt et à la diffusion de documents scientifiques de niveau recherche, publiés ou non, émanant des établissements d'enseignement et de recherche français ou étrangers, des laboratoires publics ou privés. 


\section{In situ evaluation of oxidative stress and immunological}

\section{parameters as ecotoxicological biomarkers in a novel sentinel}

\section{species (Mimachlamys varia)}

Thomas Milinkovitch $^{1 *}$, Paco Bustamante ${ }^{1}$, Valérie Huet ${ }^{1}$, Anaïs Reigner ${ }^{1}$, Carine Churlaud ${ }^{1}$, Hélène Thomas-Guyon ${ }^{1}$

\section{Affiliations}

${ }^{1}$ Littoral Environnement et Sociétés (LIENSs), UMR 7266, CNRS-Université de La Rochelle, 2 rue Olympe de Gouges, F-17042 La Rochelle Cedex 01, France. Email: thomas.milinkovitch01@univ-lr.fr; paco.bustamante@univ-lr.fr; valerie.huet@univ-lr.fr; reigner.anais@orange.fr; carine.churlaud@univ-lr.fr; helene.thomas@univ-lr.fr

* Corresponding author: T. Milinkovitch

Littoral Environnement et Sociétés (LIENSs)

UMR 7266, CNRS-Université de La Rochelle

2 rue Olympe de Gouges

F-17042 La Rochelle Cedex 01, France

Email: thomas.milinkovitch01@univ-lr.fr

Tel: $+33(0) 546507648$

Fax: $+33(0) 546458264$ 


\section{Abstract:}

Although the variegated scallop Mimachlamys varia seems to be a suitable sentinel species for contaminants monitoring, no study identified valuable responding biomarkers in this species. In order to fill this gap, this study conducted an in situ biomarker approach. M. varia were collected in contaminated and uncontaminated areas and responsiveness of oxidative stress and immunological biomarkers was evaluated in the digestive gland. In parallel, 14 trace elements concentrations were evaluated in the same organ. Superoxide dismutase activity and malondialdehyde content responded efficiently to in situ contamination when a certain degree of contamination was reached. Laccase-type phenoloxidase showed a high sensitivity but saturation of the response was highlighted for the highest contaminations. Additionally, correlations were found between biomarkers and trace elements concentrations. Taken together, results showed that biomarker approach conducted in the digestive gland of M. varia represents a sensitive analytical tool to highlight ecotoxicological issues in coastal marine ecosystems.

\section{Highlights}

In situ contamination was measured in the digestive gland of Mimachlamys varia Immunological and oxidative stress biomarkers responded to in situ contamination A biomarker approach in M. varia appears as a valuable ecotoxicological tool

Key words: Mimachlamys varia, biomarkers, trace elements, oxidative stress, phenoloxidase 


\section{Introduction}

The European Union's Marine Strategy Framework Directive (MSFD Dir. 2008/56/EC) was adopted in June 2008 and requires member states to take the necessary measures to achieve or maintain Good Environmental Status (GES) of the marine environment by 2020. In the aim of highlighting ecotoxicological issues, the chemical assessment of contaminants is an interesting first step. However, only the biomonitoring approaches can reveal the impact of contaminants on the biota. In this context, the biomarker approach aims at measuring "biochemical, cellular, physiological or behavioural variations in tissue or body samples or at the level of whole organisms that provides evidence of exposure to and/or effects of, one or more chemical pollutants (and/or radiations)" (Depledge, 1993). Such an approach requires the use of a pertinent couple "biomarkers-species", meaning that biomarkers of value should be assessed in an appropriate species. The value of a biomarker could be defined as a trade-off between its sensitivity, enabling an early alert on the environmental risk, and its significance, enabling to warn on biological impact upon high levels of biological organization (such as organisms or population) (Amiard and Amiard-Triquet, 2008). Oxidative stress biomarkers have been numerously investigated to evaluate the sub-lethal effects of several contaminants such as trace elements, persistent organic pollutants, or polycyclic aromatic hydrocarbons (reviewed in Valavanidis et al., 2006). They have been claimed by several authors as valuable biological indicators (Van der Oost et al., 2003; Valavanidis et al., 2006) due to their sensitivity as well as their significance as modulation of these parameters reflect a degradation of the functional integrity (Halliwell and Gutteridge, 1999). In the same way, immune parameters also have been investigated in several aquatic contaminated organisms (Galloway and Depledge, 2001; Hannam et al., 2010; Luna-Acosta et al., 2011; Milinkovitch et al., 2011) and they are considered valuable biomarkers due to their precocity and significance since 
altered immunity is commonly related to an impairment of organism health status (Amiard and Amiard-Triquet, 2008).

The appropriateness of species for biomonitoring (also called sentinel species) depends on several criteria such as sedentarity, collection facility and size of the areas of repartition (Rand, 1985; White, 2004). On this basis, the variegated scallop Mimachlamys varia seems to be appropriate regarding its sessility, its mode of collection (on the shore at low tide) and its large distribution (from the North Sea to the south east of the Atlantic Ocean and in Mediterranean sea, Gofas, 2014). Additionally, this species is of interest considering its very elevated incorporation and retention capacities for contaminants (Metian et al., 2009ab) which seem to be higher than the ones of currently used sentinel species such as mussels or oysters: namely, an in situ study of Bustamante et al. (2002) highlighted a 2 to 4 times higher bioaccumulation of Polonium-210 in the soft parts of M. varia than in Mytilus edulis.

However, although $M$. varia can be considered interesting and suitable for in situ biomonitoring, to the best of our knowledge, no study identified responding biomarkers of contamination in this species.

Thus, the goal of this study was to identify, in $M$. varia, valuable biomarkers that respond to in situ contamination. For this purpose, oxidative stress and immunological parameters modulations were monitored in the digestive gland of $M$. varia collected in contaminated and uncontaminated areas on the Atlantic coast of France.

Oxidative stress has been evaluated through lipid peroxidation by quantifying malondialdehyde (MDA), a metabolite of cell lipid degradation. In addition, superoxide dismutase (SOD) and catalase (CAT) activities were measured considering their important role in antioxidant response (Valavanidis et al., 2006). Immune system alteration was evaluated by assessing a phenoloxidase (PO) activity (laccase-type) since this enzymatic activity already has shown to be modulated by contaminants (Gagnaire et al., 2004; Bado- 
Nilles et al., 2008, Luna-Acosta et al., 2010) and plays an important role in the immune defense mechanism in invertebrates (Cerenius et al., 2008).

In parallel, the concentrations of 14 trace elements $(\mathrm{Ag}, \mathrm{As}, \mathrm{Cd}, \mathrm{Co}, \mathrm{Cr}, \mathrm{Cu}, \mathrm{Fe}, \mathrm{Mn}, \mathrm{Ni}, \mathrm{Pb}$, Se, Sn, V and $\mathrm{Zn}$ ) have been assessed in the digestive gland of $M$. varia since these contaminants are considered as tracers of anthropogenic inputs in coastal waters (SañudoWilhelmy and Flegal, 1992; Matthai et al., 2002) and show a preferential bioaccumulation in this organ (Bustamante and Miramand, 2004, 2005a).

\section{Materials and methods}

\subsection{In situ sampling and preparation of biochemical material}

Sampling was conducted simultaneously on 3 sampling sites the $29^{\text {th }}$ of March 2013. Sampling occurred at low tide in the infra-littoral zone of the three areas (already studied in Bustamante and Miramand, 2005b) described in Figure 1: Ré Island, La Rochelle South and La Rochelle North. Fourteen scallops (with a height above $37 \mathrm{~mm}$ ) were collected per area. The average height of the shells was $40.5 \pm 0.7 \mathrm{~mm}$ (mean $\pm \mathrm{SE}$ ) and the average weight of the soft parts was $1.61 \pm 0.2 \mathrm{~g}$ (mean $\pm \mathrm{SE}$ ) with no significant difference observed between areas. On the sampling site, the digestive gland was directly removed and stored at $-60^{\circ} \mathrm{C}$ in dry ice then at $-80^{\circ} \mathrm{C}$ back to the laboratory. The remaining soft parts of the organism were also stored at $-80^{\circ} \mathrm{C}$ for further analysis.

Digestive glands were then ground with a potter and divided into 2 samples used for trace elements and biochemical assessments of biomarkers. For trace elements samples were freeze-dried for 48 hours. For biomarkers assessment, samples were homogenised in ice-cold phosphate buffer (100 mM, pH 7.2, $1100 \mathrm{mOsm})$ containing ethylene diamine tetra acetic 
acid (EDTA $0.2 \mathrm{M}$ ) and free protease inhibitors (Halt protease inhibitor cocktail 87785, Thermo Scientific). The homogenates were centrifuged at $12500 \mathrm{~g}$ at $4{ }^{\circ} \mathrm{C}$ for $15 \mathrm{~min}$ and the post-mitochondrial fractions (PMF) were used for biochemical assays.

\subsection{Trace elements assessment}

Analyses of $\mathrm{Ag}, \mathrm{As}, \mathrm{Cd}, \mathrm{Co}, \mathrm{Cr}, \mathrm{Cu}, \mathrm{Fe}, \mathrm{Mn}, \mathrm{Ni}, \mathrm{Pb}, \mathrm{Se}, \mathrm{Sn}, \mathrm{V}$ and $\mathrm{Zn}$ were performed with a Varian Vista-Pro ICP-OES and a Thermofisher Scientific XSeries 2 ICP-MS. To this end, aliquots weighing between 0.1 to $0.2 \mathrm{~g}$ were digested using a $3: 1$ (v/v) 67-70\% HNO3 / 34$37 \% \mathrm{HCl}$ mixture (Fisher, trace metal quality). Acidic digestion of the samples was carried out overnight at room temperature and then in a Milestone microwave oven (30 min with constantly increasing temperature up to $120{ }^{\circ} \mathrm{C}$, then $15 \mathrm{~min}$ at this maximal temperature). Each sample was made up to $50 \mathrm{~mL}$ with ultrapure quality water (Milli-Q). For samples with a weight less than $0.1 \mathrm{~g}$, the mixture used was $3: 1(\mathrm{v} / \mathrm{v}) 67-70 \% \mathrm{HNO} 3 / 34-37 \% \mathrm{HCl}$ and the sample was completed with ultra pure water up to $25 \mathrm{~mL}$. Two certified reference materials (CRMs) and one blank, treated and analyzed in the same way as the samples, were included in each analytical batch. CRMs were DOLT-4 (dogfish liver) and TORT-2 (lobster hepatopancreas) both from the National Research Council Canada (NRCC). Mean element concentrations are expressed in $\mu \mathrm{g} / \mathrm{g}$ of dry weight. The detection limits were $0.02(\mathrm{Ag}), 0.25$ (As), $1.24(\mathrm{Cd}), 0.02(\mathrm{Co}), 0.02(\mathrm{Cr}), 1.24(\mathrm{Cu}), 4.97(\mathrm{Fe}), 1.24(\mathrm{Mn}), 0.05(\mathrm{Ni}), 0.02(\mathrm{~Pb})$, $0.12(\mathrm{Se}), 0.02(\mathrm{Sn}), 0.5(\mathrm{~V})$ et $4.97(\mathrm{Zn})$ in $\mu \mathrm{g} / \mathrm{g}$ of dry weight.

\subsection{Biomarkers assessment}


Protein concentrations in the PMF were determined using Bradford method (1976) with a BioRad assay kit (500-0002) that contained bovine serum albumin (BSA) as a standard and Brilliant Blue G 250 as a reactant. This reaction was measured at $570 \mathrm{~nm}$ using a spectrophotometer (SAFAS Flx-Xenius).

Lipid peroxidation was estimated by assessing the malondialdehyde (MDA) concentration in the PMF. For this purpose a commercially available MDA assay kit (Oxis International) was used. The method was based on the reaction of MDA with a chromogenic reagent (n-methyl2-phenylindole). The blue product was quantified by measuring absorbance at $586 \mathrm{~nm}$ (Gérard-Monnier et al., 1998) using the SAFAS Flx-Xenius spectrophotometer. The results are presented in nmol of MDA/mg of protein.

The SOD activity was assessed in the PMF using the method developed by Paoletti et al. (1986). The assay, involving EDTA, $\mathrm{MnCl}_{2}$ and mercaptoethanol, measured the decrease of nicotinamide adenine dinucleotide (NADH) oxidation. This inhibition of oxidation was monitored spectrophotometrically at $340 \mathrm{~nm}$ (using the SAFAS Flx-Xenius spectrophotometer) and is a function of SOD activity. Fifty percents of inhibition of oxidation correspond to one unit of SOD. The results were presented in $\mathrm{U}$ of SOD/mg of protein.

The CAT activity was assessed according to the method of Babo and Vasseur (1992). Standard and PMF catalase reduced hydrogen peroxide into oxygen and water. Consequently, the degradation of hydrogen peroxide is a function of the enzyme activity. This kinetic is assessed at $240 \mathrm{~nm}$ using the SAFAS Flx-Xenius spectrophotometer. The results were expressed in $\mathrm{U}$ of CAT/g of proteins.

Using a method developed by Luna-Acosta et al. (2010), the activity was measured in the PMF. The method is based on the fact that the oxidation of PPD (p-phenylenediamine) is catalyzed by laccase. Thus, the activity of laccase-type phenoloxidase (PO) is a function of PPD degradation. The reaction was assessed at $420 \mathrm{~nm}$ using a SAFAS Flx-Xenius 
spectrophotometer. In parallel, the non-enzymatic auto-oxidation (oxidation in the absence of PMF) was subtracted. Laccase-type PO activity was expressed as $\mathrm{U} / \mathrm{mg}$ of protein (one unit is defined as the amount of enzyme that catalyses the appearance of $1 \mu \mathrm{mol}$ of product per min).

\subsection{Statistical analysis}

The statistical analysis was carried out using Statistica software. The homoscedasticity (using Levene test) was demonstrated for all variables and one-way analyses of variance (ANOVAs) were conducted to highlight significant differences between groups. If a significant difference was detected (for $\mathrm{P}_{\text {value }}<0.05$ ), pairwise comparisons between groups were conducted using an HSD Tukey post-hoc test. A multi-correlation Spearman test was used to highlight correlations between trace elements concentrations and biomarkers values.

The results were expressed as mean \pm standard error of the mean.

\section{Results}

\subsection{Trace elements concentrations}

Trace element concentrations are presented in Table 1. Ag concentrations were significantly different between all groups with the highest contamination recorded for LR North scallops, medium contamination for LR South ones and the lowest for those from Ré island. As, Co, $\mathrm{Cr}, \mathrm{Pb}, \mathrm{V}, \mathrm{Se}$ and $\mathrm{Sn}$ concentrations showed significant higher values in LR sites (North and South) although no significant difference between these sites. For $\mathrm{Cu}$ and $\mathrm{Fe}$, only significant differences were found between LR North and Ré Island whereas for Mn and Zn, significant differences were only found between LR South and Ré Island). Cd concentrations were 
significantly higher in LR North scallops, when compared to those from Ré Island and LR South. Ni showed no significant variation of concentrations.

\subsection{Lipid peroxidation (MDA content)}

Malondialdehyde content in Ré Island scallops showed an average value of $4.09 \pm 0.50$ $\mathrm{nmol} / \mathrm{mg}$ of protein (Figure 2A). Compared to this value, LR South scallops did not show significant difference but LR North ones highlighted a higher content of $37 \%$. Pairwise comparison tests did not reveal significant difference between scallops from LR North and South.

\subsection{Superoxide dismutase (SOD)}

The SOD activity in the digestive gland of $M$. varia is presented in Figure 2B. In Ré Island, mean value was $29.40 \pm 1.82 \mathrm{U} / \mathrm{mg}$ of protein. The activity of the enzyme is not significantly higher in LR South. However, scallops from LR North showed $36 \%$ and $35 \%$ significant higher activities when compared to Ré Island and LR South ones, respectively.

\subsection{Catalase (CAT)}

The mean CAT activity in the digestive gland of Mimachlamys varia was $426.8 \pm 72.8 \mathrm{U} / \mathrm{g}$ of protein in Ré Island scallops (Figure 2C). No significant difference was observed between sampling sites. Enzyme activities showed a high intra-group variability.

\subsection{Laccase-type PO activity}


Laccase-type PO activity (Figure 2D) was $2.53 \pm 0.20 \mathrm{U} / \mathrm{mg}$ of protein in the digestive gland of organisms sampled in Ré island. When compared to this value, the activity in the digestive gland of South and North LR scallops is higher (64 and $28 \%$, respectively). No significant difference was observed when conducting a statistical comparison between South and North LR groups.

3.6 Correlations between biomarkers responses and trace elements concentrations (Table 2)

Multi-correlation test was conducted between trace elements concentrations and biomarkers values. It revealed: (i) significant correlations of $\mathrm{SOD}$ activity with $\mathrm{Ag}, \mathrm{Co}, \mathrm{Cd}, \mathrm{Ni}$, and $\mathrm{V}$, and a trend toward correlation with $\mathrm{Cr}(\mathrm{P}=0.09)$; (ii) no correlation of CAT activity with any of the considered trace elements; (iii) significant correlations of MDA content with $\mathrm{Cr}$ and $\mathrm{V}$ and trends toward correlation with $\mathrm{Ag}(\mathrm{P}=0.09), \mathrm{Cd}(\mathrm{P}=0.07), \mathrm{Co}(\mathrm{P}=0.08)$ and $\mathrm{Pb}(\mathrm{P}=0.06)$; (iv) significant correlations of laccase-type PO activity with all trace elements except with Ag and Sn.

\section{Discussion}

In order to identify responsive and valuable biomarkers of contamination in $M$. varia, oxidative stress and immunological parameters were assessed in organisms collected in several areas potentially differentially contaminated: Ré Island, previously identified as a reference site; LR South and LR North, subjected to important industrial and domestic contamination (Bustamante et al. 2002, Bustamante and Miramand 2004, 2005a,b). Levels of contamination of each area were estimated by assessing the trace elements concentrations in 
the digestive glands of $M$. varia since these contaminants (and particularly Ag) are considered valuable tracers of sewage in coastal waters (Sañudo-Wilhelmy and Flegal, 1992).

Regarding all trace elements (excepted $\mathrm{Cd}, \mathrm{Cr}, \mathrm{Cu}$ and $\mathrm{Fe}$ ), results highlight a higher contamination of LR South, when compared to the reference site (Ré Island). In the same way, regarding all trace elements (excepted $\mathrm{Fe}, \mathrm{Mn}$ and $\mathrm{Zn}$ ), the contamination is also higher in LR North than in the reference site. Taken together, these results confirmed that LR South and North remained highly contaminated about decades after the previous studies of Bustamante et al. (2002) and Bustamante and Miramand (2004, 2005a,b). Moreover, while most of the trace elements concentrations did not permit to highlight differences between the three sampling sites, Ag exposed a range of contamination consistent with the release from the different activities from the city of La Rochelle (Figure 1): contamination was the highest in LR North, intermediate in LR South and the lowest in Ré Island. These results confirmed the fact that $\mathrm{Ag}$ is a sensitive tracer of sewage in coastal waters (Sañudo-Wilhelmy and Flegal, 1992; Matthai et al., 2002) and suggested that anthropogenic inputs are more intense in LR North than in LR South.

While trace element measurements in the digestive gland of $M$. varia informed on the general anthropogenic sewage in coastal waters and also validated the choice of the three sampling sites, this assessment revealed also, more particularly, the contamination and thus the potential biological effects (response, toxicity) of trace elements. Regarding this link between trace elements bioaccumulation and biological effects, a specific attention could be given to non-essential metals (in the present study $\mathrm{Ag}, \mathrm{Cd}$ and $\mathrm{Pb}$ ) since these elements are not required by the organism and are thus likely to involve forthwith biological effects and then toxicity (Rainbow, 2002). Taken together, the concentrations of these 3 elements in the 3 sampling sites described a pattern showing the highest contamination in LR North, a medium one in LR South and the lowest for Ré Island. 
In summary, the trace elements concentrations highlighted three sampling sites with different degrees of contamination: high, medium and low (or reference) contaminated sites.

Using $M$. varia from these three sites, this study aims at identifying biomarkers that efficiently respond to in situ contamination. For this purpose, biomarkers of oxidative stress were assessed in M. varia from LR North, LR South and Ré Island. Lipid peroxidation was evaluated through MDA content which values ranged between 4.1 and $5.6 \mathrm{nmol} / \mathrm{mg}$ of protein (in Ré Island and LR North, respectively). Our results showed significantly higher contents of MDA in the digestive gland of scallops sampled in LR North than in the ones collected from Ré Island. This result highlighted an enhanced lipid peroxidation in the scallops from the contaminated site. This is consistent with the results of Liu et al. (2012) who also showed this phenomenon studying $C$. farreri from uncontaminated and contaminated sites. Although the contents of MDA in $M$. varia from LR South seems to be higher than those from Ré Island and lower than those from LR North, no significant difference was observed. This shows that no modulation of lipid peroxidation occurred in organisms from LR South, when compared to the reference site. Taken together these results suggest that MDA, assessed in the digestive gland of M. varia, is a biomarker responding efficiently to in situ contamination, although a certain degree of contamination is required to induce this response.

Consequently, in order to identify the biomarkers that respond to an intermediate degree of contamination, this study also investigated the modulation of more sensitive oxidative stress biomarkers. For this purpose SOD and CAT activities were evaluated since these enzymes are considered as precocious biomarkers linked to oxidative stress, their induction (by reactive oxygen species, ROS) appearing before oxidative damages (Valavanidis et al., 2006).

Regarding SOD activity, values ranged between 29.4 and $40.7 \mathrm{U} / \mathrm{mg}$ of protein for scallops collected in Ré Island and LR North, respectively. 
The significant higher SOD activity in LR North (when compared to Ré Island) is in accordance with several studies conducted in pectinidae that showed a modulation of this enzyme activity due to contaminants (Pan et al., 2005, 2006, 2009; Zhang et al, 2010). This higher activity revealed an antioxidant response (probably induced by ROS) in LR North organisms. However, in the same way than for MDA, SOD activity was significantly not different in LR South than in Ré Island suggesting that SOD responds efficiently to contamination although a degree of contamination is necessary.

Concerning CAT activities, no significant difference was found between the three groups of organisms (probably due to the high intra group variability) suggesting that this biomarker is not responsive enough to be used in future biomonitoring studies with $M$. varia.

In contrast, MDA contents and SOD activity can be considered responsive enough to be used for in situ biomonitoring studies with M. varia as a sentinel species. However, results also show that oxidative stress seems to not be induced by intermediate contaminations showing the need to consider biomarkers related to other key physiological function. For this purpose, a biomarker of immune system, laccase-type PO was assessed in the digestive gland.

Concerning laccase-type PO, our results revealed a significant higher PO activity in the two contaminated sites (LR South and North), when compared to the reference site. This result is in accordance with Luna-Acosta et al. (2011 and 2012) who revealed a modulation of the enzyme activity with different type of contaminants (hydrocarbons as well as herbicides and pharmaceuticals, respectively). Since both contaminated sites revealed a biomarkers response, these results suggest that laccase-type PO activity is a sensitive biomarker responding to any degrees of contamination. However, no significant difference was highlighted between contaminated sites. This could be due to a saturation of the response of laccase-type PO activity to contaminants: the higher contaminant stress did not induce a more important response of the enzyme. 
Thus, results of this study showed several biomarkers responding to in situ contamination. Although identifying exactly the contaminants that are involved in this biomarkers response is barely possible, correlations tests were conducted to give information on this issue. Results revealed similarities in the correlation patterns of both responding biomarkers of oxidative stress (i.e. SOD and MDA). Indeed, both biomarkers showed correlations or trends toward correlations with $\mathrm{Ag}, \mathrm{Co}, \mathrm{Cd}, \mathrm{Cr}$ and $\mathrm{V}$. These correlations suggest that oxidative stress could be due, in a part to (i) these trace elements bioaccumulation or/and (ii) the contamination by sewage since trace elements (and more particularly Ag) are tracers of this type of contamination. Results also revealed discrepancies in the patterns of correlation between responding biomarkers and trace elements. Indeed, while $\mathrm{Cu}$ and $\mathrm{Ni}$ were correlated to SOD activity, no correlation was observed with MDA content. This could be due to the fact that, in this case, the SOD response was efficient enough to prevent the lipid peroxidation induced by these two trace elements. Consequently the incorporation of $\mathrm{Cu}$ and $\mathrm{Ni}$ did not induce higher MDA contents. Regarding to the correlation between laccase type-PO and trace elements, results showed correlations for all trace elements except for Ag. This suggests that modulation of laccase-type PO activity is in part due to trace elements bioaccumulation but seems not being due to sewage contamination.

Although trace elements concentrations have been shown to be correlated with biomarkers responses, other in situ parameters could also have effects on this response. Among the several natural abiotic factors, oxygen level, temperature and salinity are the most likely to modulate oxidative stress (Luschak, 2011) as well as immunological parameters in aquatic animals (e.g. Wang et al., 2012; Munari et al., 2011). In this study, variation of these parameters could be partly involved in the biomarkers modulation observed. However, monitoring conducted 5 days before and after the sampling date in two sites closed to the sampling areas $(46.278,-1.377$ and $46.055,-1.131)$, revealed slight variability of these 
parameters: the average water surface temperature was 8.6 and $9.2^{\circ} \mathrm{C}$ (in both sites respectively), salinity was 32.3 and $30.3 \%$, and hypoxia was 9.4 and $9.9 \mathrm{mgO}_{2} / \mathrm{L}$ (data from IFREMER database via personal communication Yann Coupeau).

\section{Conclusion}

By assessing the modulation of oxidative stress and immunological parameters in the digestive gland of $M$. varia, collected in contaminated and uncontaminated areas, this study highlighted biomarkers responding to in situ contamination. Both SOD and MDA, as biomarkers of oxidative stress, responded efficiently to in situ contamination although a certain degree of contamination was necessary to trigger this response. Laccase-type PO higher activity was induced by intermediate and high levels of contamination but no difference could have been highlighted between these two different degrees of contamination. Thus, each biomarker cannot independently differentiate the different degrees of contamination, but, considering the three responding biomarkers, three levels of biological effects, corresponding to the three levels of contamination, could be discerned. Such results showed that a biomarker approach in $M$. varia could be a sensitive and valuable tool to highlight ecotoxicological issues. However, the responsiveness of several other biomarkers (linked to several organism functions) should be investigated in order to support these conclusions. Additionally, complementary studies, comparing the responsiveness of common biomarkers in the variegated scallop and in conventional species used for biomonitoring (such as mussels or oysters), could be of great interest in order to assess the value of $M$. varia as a sentinel species. Indeed, little information is available on this topic: to the best of our knowledge only one biomonitoring study conducted by Cotou et al. (1998) highlighted a 
higher concentration of methallothionein in the soft parts of $M$. varia when compared to the blue mussel Mytilus galloprovincialis.

\section{Acknowledgements}

Postdoctoral fellow, mobility grants and experimentation costs for this work were supported by grants from the Ambassade Royale de Norvège (Norway) and the Ministère des Affaires Etrangères (France). Parts of the experimentation costs were supported by Centre National de la Recherche Scientifique (CNRS), FEDER, Conseil Régional Poitou-Charentes (France) and the RISPECT project. The authors thank N. Lachaussée and P. Pineau for their help collecting the scallops.

\section{References}

Amiard, J. C., Amiard-Triquet, C., 2008. Les biomarqueurs dans l'évaluation de l'état écologique des milieux aquatiques. Paris. pp. 372.

Babo, S., Vasseur, P., 1992. In vitro effects of Thiram on liver antioxidant enzyme activities of rainbow trout (Oncorhynchus mykiss). Aquatic Toxicology, 22, 61-68.

Bado-Nilles, A., Gagnaire, B., Thomas-Guyon, H., Le Floch, S., Renault, T., 2008. Effects of 16 pure hydrocarbons and two oils on haemocyte and haemolymphatic parameters in the Pacific oyster, Crassostrea gigas (Thunberg). Toxicology In Vitro, 1610-1617.

Bradford, M. M., 1976. A rapid sensitive method for the quantitation of microgram quantities of protein utilizing the principle of protein-dye binding. Analytical Biochemistry 72, 248-254. Bustamante, P., Germain, P., Leclerc, G., Miramand, P., 2002. Concentration and distribution of ${ }^{210} \mathrm{Po}$ in the tissues of the scallop Chlamys varia and the mussel Mytilus edulis from the coasts of Charente-Maritime (France). Marine Pollution Bulletin 44, 997-1002 
Bustamante, P., Miramand, P., 2004. Interspecific and geographical variations of trace element concentrations in Pectinidae from European waters. Chemosphere 57, 1355-1362 Bustamante, P., Miramand, P., 2005a. Evaluation of the variegated scallop Chlamys varia as a biomonitor of temporal trends of $\mathrm{Cd}, \mathrm{Cu}$, and $\mathrm{Zn}$ in the field. Environmental pollution, 138, $109-120$.

Bustamante, P., Miramand, P., 2005b. Subcellular and body distributions of 17 trace elements in the variegated scallop Chlamys varia from the French coast of the Bay of Biscay. Science of the total environment, 337, 59-73

Cerenius, L., Lee, B., Söderhäll, K., 2008. The proPO-system: Pros and cons for its role in invertebrate immunity. Trends in Immunology 29, 263-271

Depledge, M.H., 1993. The Rational Basis for the Use of Biomarkers as Ecotoxicological Tools. In: Fossi, M.C., Leonzio, C., Non destructive biomarkers in vertebrates. Lewis Publishers, Boca Raton, Florida, 271-295

Gagnaire, B., Thomas-Guyon, H., Renault, T., 2004. In vitro effects of cadmium and mercury on Pacific oyster, Crassostrea gigas (Thunberg), haemocytes. Fish and Shellfish Immunology, 16, 501-512.

Galloway, T.S., Depledge, M.H., 2001. Immunotoxicity in invertebrates: measurement and ecotoxicological relevance. Ecotoxicology, 10, 5-23.

George, S.G., 1990. Biochemical and cytological assessments of metal toxicity in marine animals. In: Furness, R.W., Rainbow, P.S. (Eds.), Heavy Metals in the Marine Environment. CRC Press, Boca Raton, Florida, pp. 123-142.

Gofas, S., Mimachlamys varia (Linnaeus, 1758). Accessed through: World Register of Marine Species at http://www.marinespecies.org/aphia.php?p=taxdetails\&id=236719

Halliwell, B., Gutteridge, J. M. C., 1999. Free radicals in biology and medecine. Oxford University Press, Oxford. pp. 192. 
Hannam, M.L., Bamber, S.D., Moody, A.J., Galloway, T.S., Jones, M.B., 2010. Immunotoxicity and oxidative stress in the Arctic scallop Chlamys islandica: Effects of acute oil exposure. Ecotoxicology and Environmental Safety 73, 1440-1448

Liu, N., Pan, L., Wang, J., Yang, H., Liu, D., 2012. Application of the biomarker responses in scallop (Chlamys farreri) to assess metals and PAHs pollution in Jiaozhou Bay, China. Marine Environmental Research 80, 38-45

Lushchak, V.I., Environmentally induced oxidative stress in aquatic animals Aquatic Toxicology 101, 13-30

Luna-Acosta, A., Rosenfeld, E., Amari, M., Fruitier-Arnaudin, I., Bustamante, P., ThomasGuyon, H., 2010. First evidence of laccase activity in the Pacific oyster Crassostrea gigas. Fish and Shellfish Immunology 28, 719-726.

Luna-Acosta, A., Kanan, R., Le Floch, S., Huet, V., Pineau P., Bustamante P., ThomasGuyon H., 2011. Enhanced immunological and detoxification responses in Pacific oysters, Crassostrea gigas, exposed to chemically dispersed oil. Water research 45, 4103-4118

Luna-Acosta, A., Renault, T., Thomas-Guyon, H., Faury, N., Saulnier, D., Budzinski H., Le Menach, K., Pardon, P., Fruitier-Arnaudin, I., Bustamante, P., 2012. Detection of early effects of a single herbicide (diuron) and a mix of herbicides and pharmaceuticals (diuron, isoproturon, ibuprofen) on immunological parameters of Pacific oyster (Crassostrea gigas) spat. Chemosphere $87,1335-1340$

Matthai, C., Birch, G.F., Bickford, G.P., 2002. Anthropogenic trace metals in sediment and settling particulate matter on a high-energy continental shelf (Sydney, Australia). Marine Environmental Research 54, 99-127

Metian, M., Bustamante, P., Hédouin, L., Oberhänsli, F., Warnau, M., 2009a. Delineation of heavy metal uptake pathways (seawater and food) in the variegated scallop Chlamys varia using radiotracer techniques. Marine Ecology Progress Series, 375, 161-171. 
Metian, M., Warnau, M., Teyssié, J-L., Oberhänsli, FR., Bustamante, P., 2009b. Delineation of $\mathrm{Pb}$ contamination pathways in two species of Pectinidae: the variegated scallop (Chlamys varia) and the king scallop (Pecten maximus). Science of the Total Environment, 407, 35033509.

Milinkovitch, T., Sanchez, W., Ndiaye, A., Le Floch, S., Thomas-Guyon, H., 2011. Liver antioxidant responses and innate immune function in golden grey mullet (Liza aurata) following exposure to dispersed crude oil. Aquatic Toxicology 101, 155-164.

Munari, M., Matozzo, V., Marin, M.G., 2011. Combined effects of temperature and salinity on functional responses of haemocytes and survival in air of the clam Ruditapes philippinarum. Fish \& Shellfish Immunology 30, 1024-1030

Pan L., Ren, J., Liu, J., 2005. Effects of benzo(k)fluoranthene exposure on the biomarkers of scallop Chlamys farreri. Comparative Biochemistry and Physiology Part C 141, 248 - 256

Pan, L.Q., Ren, J., Liu, J., Responses of antioxidant systems and LPO level to benzo(a)pyrene and benzo(k)fluoranthene in the haemolymph of the scallop Chlamys Ferrari. Environmental Pollution 141, 443-451

Pan, L.Q., Ren, J., Zheng, D., 2009. Effects of benzo(a)pyrene exposure on the antioxidant enzyme activity of scallop Chlamys farreri. Chinese Journal of Oceanology and Limnology $27,43-53$

Paoletti, F., Aldinucci, D., Mocali, A., Caparrini, A., 1986. A sensitive spectrophotometric method for the determination of superoxide dismutase activity in tissue extracts. Analytical Biochemistry 154, 536-541.

Rainbow, P.S., 2002. Trace metal concentrations in aquatic invertebrates: why and so what? Environmental Pollution 120, 497-507 
Rand, G.M., 1985. Behavior. In: Rand, G.M., Petrocelli, S.R. Fundamentals of aquatic toxicology: methods and applications. Hemisphere Publishing Corp., Washington DC, 221263

Sanudo-Wilhelmy, S.A., Flegal, A.R., 1992. Anthropogenic silver in the Southern California Bight: a new tracer of sewage in coastal waters. Environmental Science and Technology, 26, $2147-2151$.

Van der Oost, R., Beyer, J., Vermeulen, N. P. E. 2003. Fish bioaccumulation and biomarkers in environmental risk assessment: a review. Environmental Toxicology and Pharmacology, $13,57-149$.

Valavanidis, A., Vlahogiannia, T., Dassenakis, M., Scoullos, M., 2006. Molecular biomarkers of oxidative stress in aquatic organisms in relation to toxic environmental pollutants Ecotoxicology and Environmental Safety 64, 178-189

White, G.J., 2004. Selection of ecological indicators for monitoring terrestrial systems. In: Wiersma, G.B. Environmental monitoring. CRC Press, Boca Raton, 263-282

Wang Y., Hu, M., Cheung, S.G., Shin, P.K.S., Lu, W., Li, J., 2012. Immune parameter changes of hemocytes in green-lipped mussel Perna viridis exposure to hypoxia and hyposalinity. Aquaculture 356-357, 22-29

Zhang, Y., Song, J., Yuan, H., Xu, Y., He, Z., Duan, L., 2010. Biomarker responses in the bivalve (Chlamys farreri) to exposure of the environmentally relevant concentrations of lead, mercury, copper. Environmental Toxicology and Pharmacology 30, 19-25 
Table 1: Trace elements concentrations ( $\mu \mathrm{g} / \mathrm{g}$ of dry weight) in the digestive glands of Mimachlamys varia ( $\mathrm{n}=14$ per sites) from the three sampling areas (Ré Island, LR South, LR North). Different letters ( ${ }^{\mathbf{a}, \mathbf{b}}$ and/or ${ }^{\mathbf{c}}$ ) above values indicate a significant difference, where $\mathrm{P}$ $<0.05$.

\begin{tabular}{|c|c|c|c|}
\hline & \multicolumn{3}{|c|}{ Sampling sites } \\
\hline & Ré Island & LR South & LR North \\
\hline $\mathrm{Ag}$ & $4.07 \pm 0.83^{\mathbf{a}}$ & $9.06 \pm 1.45^{\mathbf{b}}$ & $16.94 \pm 1.16^{\mathrm{c}}$ \\
\hline As & $10.17 \pm 1.48^{\mathbf{a}}$ & $14.04 \pm 0.14^{\mathbf{b}}$ & $14.99 \pm 0.81^{\mathbf{b}}$ \\
\hline $\mathrm{Cd}$ & $12.76 \pm 1.72^{\mathbf{a}}$ & $25.74 \pm 5.22^{\mathbf{a}}$ & $42.04 \pm 3.58^{\mathbf{b}}$ \\
\hline Co & $0.57 \pm 0.08^{\mathbf{a}}$ & $0.92 \pm 0.08^{\mathbf{b}}$ & $0.97 \pm 0.06^{\mathbf{b}}$ \\
\hline $\mathrm{Cr}$ & $0.93 \pm 0.15^{\mathbf{a}}$ & $1.72 \pm 0.19^{\mathbf{a} \cdot \mathbf{b}}$ & $1.63 \pm 0.07^{\mathbf{b}}$ \\
\hline $\mathrm{Cu}$ & $17.38 \pm 1.77^{\mathbf{a}}$ & $54.77 \pm 22.92^{\mathbf{a . b}}$ & $102.42 \pm 12.84^{\mathbf{b}}$ \\
\hline $\mathrm{Fe}$ & $677 \pm 115^{\mathrm{a}}$ & $1115 \pm 82^{\mathbf{b}}$ & $887 \pm 54^{\mathbf{a} \cdot \mathbf{b}}$ \\
\hline $\mathrm{Mn}$ & $17.27 \pm 2.81^{\mathbf{a}}$ & $32.14 \pm 1.52^{\mathbf{a}}$ & $23.97 \pm 1.41^{\mathbf{a}}$ \\
\hline $\mathrm{Ni}$ & $1.77 \pm 0.27^{\mathbf{a}}$ & $2.61 \pm 0.23^{\mathbf{b}}$ & $2.57 \pm 0.13^{\mathbf{b}}$ \\
\hline $\mathrm{Pb}$ & $1.36 \pm 0.22^{\mathbf{a}}$ & $2.32 \pm 0.17^{\mathbf{b}}$ & $2.03 \pm 0.09^{\mathbf{b}}$ \\
\hline $\mathrm{Se}$ & $5.23 \pm 0.79^{\mathbf{a}}$ & $8.83 \pm 0.25^{\mathbf{b}}$ & $8.55 \pm 0.5^{\mathbf{b}}$ \\
\hline $\mathrm{Sn}$ & $0.042 \pm 0.0095^{\mathbf{a}}$ & $0.084 \pm 0.0018^{\mathbf{b}}$ & $0.095 \pm 0.0059^{\mathbf{b}}$ \\
\hline $\mathrm{V}$ & $2.29 \pm 0.41^{\mathbf{a}}$ & $4.07 \pm 0.13^{\mathbf{b}}$ & $4.75 \pm 0.31^{\mathbf{b}}$ \\
\hline $\mathrm{Zn}$ & $59.5 \pm 10.3^{\mathbf{a}}$ & $124 \pm 11.5^{\mathbf{b}}$ & $90.63 \pm 6.01^{\mathbf{a} \cdot \mathbf{b}}$ \\
\hline
\end{tabular}


Table 2: Correlations between biomarkers responses and trace elements concentrations in the digestive glands of Mimachlamys varia ( $\mathrm{n}=14$ per sites) from the three sampling areas (Ré Island, LR South, LR North). $<0.05$ indicates a significant correlation where $\mathrm{P}$ value $<0.05$. $<0.1$ indicates a trend toward correlation where $\mathrm{P}$ value $<0.1$. - indicates no trend toward correlation neither significant correlation. MDA: malondialdehyde; SOD: superoxide dismutase; CAT: catalase; Lac-PO: laccase-type PO

\begin{tabular}{lcccc}
\hline & MDA & SOD & CAT & Lac-PO \\
\hline $\mathrm{Ag}$ & $<0.1$ & $<0.05$ & - & - \\
$\mathrm{As}$ & - & - & - & $<0.05$ \\
$\mathrm{Cd}$ & $<0.05$ & - & $<0.05$ \\
$\mathrm{Co}$ & $<0.1$ & 0.05 & - & $<0.05$ \\
$\mathrm{Cr}$ & $<0.1$ & $<0.1$ & - & $<0.05$ \\
$\mathrm{Cu}$ & -0.05 & - & - & $<0.05$ \\
$\mathrm{Fe}$ & - & - & $<0.05$ \\
$\mathrm{Mn}$ & - & - & $<0.05$ \\
$\mathrm{Ni}$ & - & -0.05 & - & $<0.05$ \\
$\mathrm{~Pb}$ & $<0.1$ & - & - & $<0.05$ \\
$\mathrm{Se}$ & - & - & - & $<0.05$ \\
$\mathrm{Sn}$ & - & -0.05 & - & $<0.1$ \\
$\mathrm{~V}$ & $<0.05$ & - & - & $<0.05$ \\
$\mathrm{Zn}$ & - & - & -05 \\
\hline
\end{tabular}




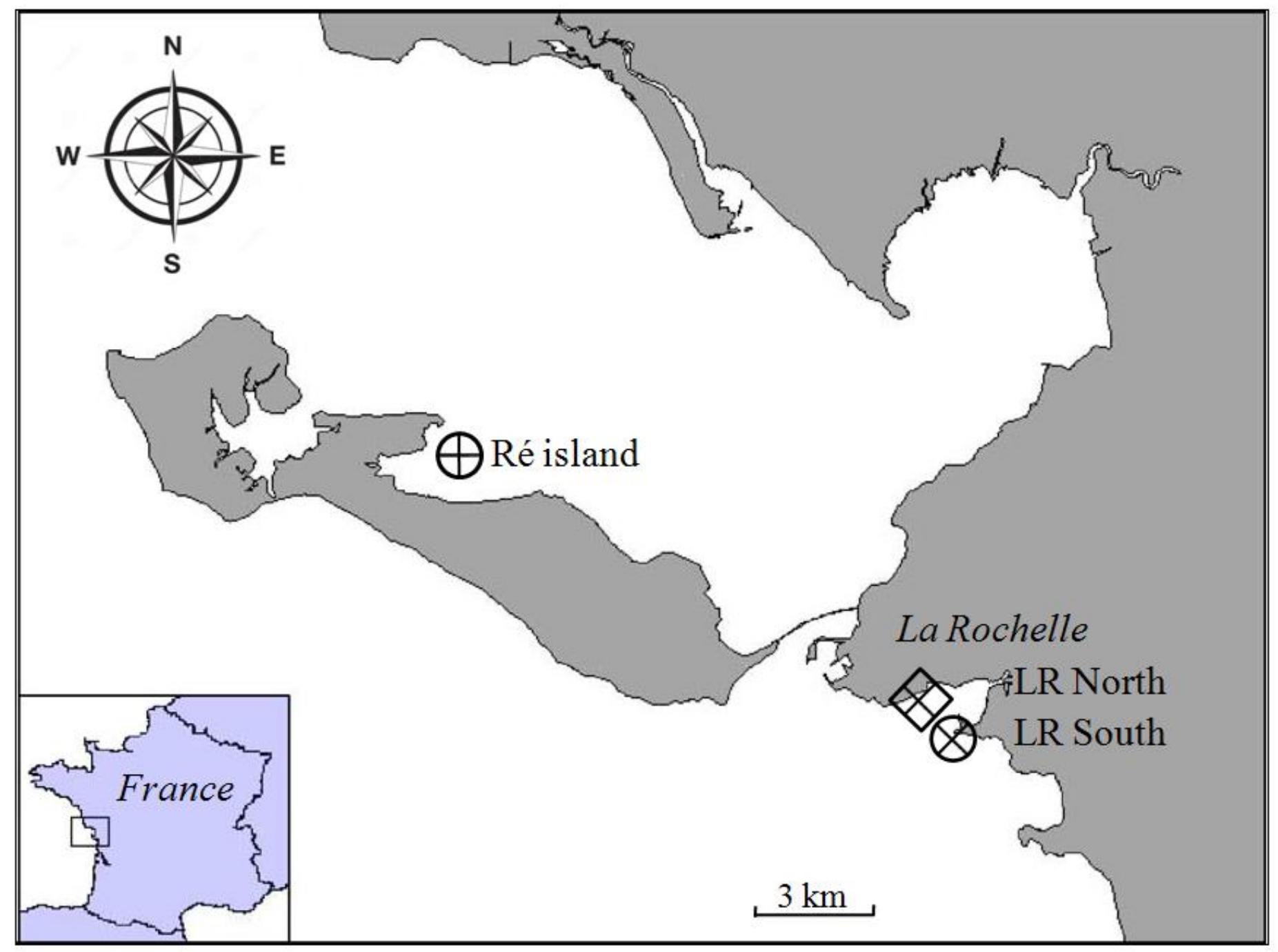

Figure 1: Location of the three sampling areas: Ré island $(\bigoplus$, geographical coordinates: 46.220, -1.404), LR South ( $($, geographical coordinates: 46.137, -1.175) and LR North ( $\otimes$, geographical coordinates: 46.149, -1.189). Adapted from Bustamante and Miramand, 2005b 


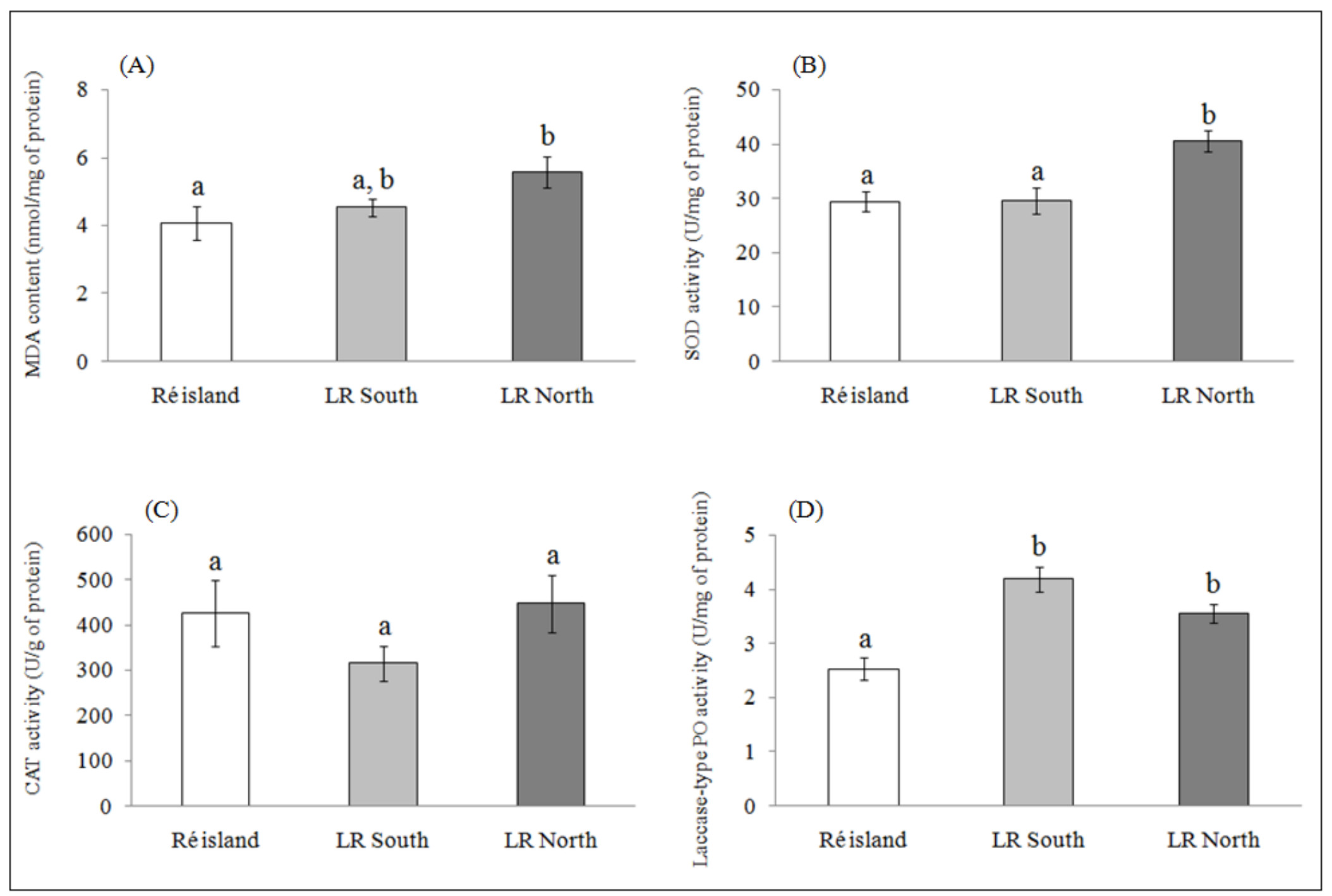

Figure 2: Biomarkers assessed in the PMF of Chlamys varia digestive glands from Ré island, LR South and LR North. (A) MDA contents, (B) Superoxide Dismutase (SOD) activity, (C) Catalase (CAT) activity, (D) Laccase-type PO activity. Values represent mean \pm standard error (n=14 per sites). Different letters above bars (a, b and/or c) indicate a significant difference, where $\mathrm{P}<0.05$. 